\title{
Embracing Neapolitan as a Language Which Is Key to the Reconstruction of Early Romance
}

\author{
John M. Ryan \\ University of Northern Colorado, Greely, Colorado, USA
}

\begin{abstract}
Despite being the second most spoken language on the Italian peninsula, Neapolitan has been overlooked in some of the more important comparative linguistic studies of the twentieth and twenty-first centuries. A survey of these studies suggests the preference for: 1) national languages, in this case, Italian, 2) languages that possess comparably the largest number of speakers, especially those that have swelled exponentially for reasons of immigration, as in the cases of Spanish, Portuguese and French; or 3) insular languages such as Sardinian which, despite its relatively low number of speakers, appears to have been included because of its sequestered history and the inevitability of differently evolved forms. The reason for this study is to demonstrate that because of exclusion among the ranks of other more elite languages, certain key structures of Neapolitan have been overlooked as potential exemplars of earlier forms of Romance. This paper suggests reasons for why the exclusion of Neapolitan in previous comparative language studies has only served to obscure the relevance of other factors that are key to the reconstruction of early Romance. The paper will also provide specific examples from the Neapolitan lexicon that serve to demonstrate how this variety conserves early forms of Romance.
\end{abstract}

Index Terms - methodology, comparative method, Neapolitan, Proto-Romance, minority languages

\section{INTRODUCTION}

Neapolitan has unique socio-historical and geographical importance in the history of Romance that has all too often been overlooked among traditional, more generalized comparisons of the Romance languages, particularly when trying to ascertain more general or historical trends of this language family as a whole. Be it because of Neapolitan's relegation to a status of purported "minority" European language or dialect, even among specialists, cross-linguistic studies have traditionally passed on Neapolitan as a viable source of data for such comparisons. ${ }^{1}$

A bird's eye analysis of existing cross-linguistic studies suggests that these have traditionally been biased toward: 1) national or "mainstream" languages, in this case, for example, Italian, suggesting Neapolitan to be a mere offshoot, despite its separate evolution from Latin, and even more surprisingly, its having been reported as being unintelligible to speakers of standard Italian from northern regions; ${ }^{2}$ 2) languages that possess a comparably large number of speakers, especially those that have swelled exponentially for reasons of immigration or empire building, such as the cases of Spanish, Portuguese and French; or 3) in more recent cases, languages that are sequestered by distance or sea, such as Romanian, Sicilian, and Sardinian, with inevitable developmental differences that have resulted from either physical isolation from, or the persistent lack of contact with, other mainland Western European Romance varieties.

A problem with the first two above-mentioned language selection methods for cross-linguistic studies is that both appear to be based on more arbitrary than scientific premises, especially when one considers the historical facts surrounding the origins, rise, and modern endurance of Neapolitan (and its continuum of dialects) throughout the southern half of Italy. I say this because the languages that have evolved to either possess official status or that have large numbers of speakers have not always been characterized as such historically, either type having had to originate at some more primitive or comparably humble point in their respective histories. Nonetheless, for reasons that are almost always entirely political, and consequently, a-linguistic, certain languages outpace others over time because they become more powerful, economically successful, and historically influential in becoming a standard means of communication, even in areas where other, less prestigious varieties continue to thrive in less formal circumstances alongside the new imposed norm. This, in turn allows them to spread exponentially, especially with historical empirebuilding efforts. This happens at the expense of those other varieties which, to no fault of their own, and many times because of disadvantages that have been imposed on them beyond their control, become relatively less prominent over time, some even resulting in extinction.

For these reasons, of all three apparent criteria for language selection mentioned previously, the third one, namely, that of isolation, appears to be a more rigorous linguistic criterion than that of, say, historical popularity or political

\footnotetext{
${ }^{1}$ This is not to say that other, less comparative work specific to Neapolitan or its structures have been altogether ignored, such as the cases of important work by Ledgeway (2009); Abete (2011); or Loporcaro (2016), to name a few.

${ }^{2}$ Ethnologue (2017) reports that according to F. Agard (1984) and Vincent (1987), "northern varieties (of Italian) are more similar to French and Occitan than to standard or southern varieties."
} 
importance. In both Hall (1976) and Hall (1984), Sardinian appears to have been included among the ten languages compared precisely because of its geographic isolation, despite its overwhelmingly small number of speakers. ${ }^{3}$

\section{PURPOSE}

The purpose of this article is to raise awareness of Neapolitan as an important but underexplored variety of Romance, particularly regarding information it can provide in terms of how it compares with the other modern Romance languages, most particularly, Spanish and Italian, and the implications this has for what have been reported as earlier transitional forms of Romance. I will show that despite its geographical proximity in relation to the western seat of the empire, Neapolitan has witnessed a continuous historical disadvantage in its having been deemed a comparably less prestigious variety of Romance, one traditionally associated with the poorer, uneducated, and/or agricultural classes of society. I will also show how the region in which Neapolitan has developed and is now spoken has been throughout most of its history subjugated to external political forces, and therefore, undervalued as the locus of a potential political power in its own right. These factors have in turn led to the outright omission of Neapolitan among the more important comparative Romance linguistic studies of the twentieth century and into the twenty first, suggesting not only that certain important data may have been overlooked in such studies, but even more importantly, that this newly defined area may now provide some new insights into the history of the other Romance languages, including Spanish.

\section{DISCUSSION}

Although technically used to describe characteristics pertaining to the customs or language spoken in or around Naples, the term Neapolitan has become a catchall, macrodialectal term used to describe most Italian dialects in the south, particularly in the Campania region (Ledgeway, 2009). ${ }^{4}$

The "southern vernacular," a more general term that has also been applied to encompass the geographical expanse of this variety, has been shown to exhibit a number of linguistic characteristics that are quite different from those of northern or standard Italian, the latter which is also known as Tuscan (Clivio et al., 2011, p. 10), and more specifically, Florentine (Maiden, 1995, pp. 3-5), and has experienced an evolution from Latin that is entirely separate from the north (Ledgeway, 2009, pp. 5-13). In fact, Neapolitan is considered a separate language from Italian with "limited inherent intelligibility" and spoken "vigorously" by 5.7 million people and often in some combination with or apart from standard Italian, and/or a local/regional variety, depending on the situation of the speaker (Ethnologue, 2017). ${ }^{5}$

As we shall see, one of the principal linguistic differences between Neapolitan and Italian is the extent of preservation of archaic structures in the former, which can be explained by its history, isolation, and economy. Southern Italy has endured a long history of political, cultural, and linguistic separatism from the north, one that included incessant natural disasters, rampant poverty, disease, and limited education and illiteracy (Bartalesi-Graf, 2011, pp. 131). Even after the unification of Italy in 1861, the North and South remained essentially un-united linguistically until the mid-1900s. ${ }^{6}$

Not until the 1950s did mass education and technology help spread the use of Tuscan as the official language. Before this time, it was not uncommon for the uneducated to speak ONLY the southern vernacular. Still today, the North and South remain two very different places both culturally and linguistically.

Southern Italy is historically an agricultural economy, although there have been several unsuccessful attempts to bring more industry into the region. This continued way of life with little improvement has contributed historically to successive, documented massive emigrations of unskilled workers from the South to places like the United States and Latin America, particularly during the early twentieth century, which as we shall see later in this paper, has had the overall effect of further depleting the numbers of current speakers of this variety. This is also responsible for the very little cultural or linguistic change within the region throughout its history, with more people leaving the region than newcomers settling there.

\section{A. Neapolitan's Absence in Previous and Current cross Linguistic Studies}

Despite being the second most spoken language in the Italian peninsula, ${ }^{7}$ Neapolitan has never been considered one of the major Romance languages. Examples abound of important comparative Romance studies in which Neapolitan is not included. Some examples are: 1) Boyd-Bowman's Latin to Romance sound charts (1980) which compare only the four so-called major national European Romance languages of Spanish, Portuguese, French, and Italian 2) Hall's seminal works on both Proto-Romance phonology (Hall, 1976) and morphology (Hall, 1984), which include Sardinian, despite reportedly having approximately 1.1 million speakers (in contrast with Neapolitan's 5.7 million); and more recently, 3) Rudder's Romance grammar (2012).

\footnotetext{
${ }^{3}$ Interestingly, both Hall (1976) and Hall (1984) also include, in addition to modern French, Old North French and Old South French among their roster of languages for comparison.

${ }^{4}$ Not unlike the term "castellano" in the Spanish-speaking world that technically refers to the variety of Spanish that originated and is still spoken in Castile, but is applied more liberally by speakers of most other regional varieties of Spanish.

${ }^{5}$ According to Ethnologue (2017), estimates for Neapolitan-Calabrese and other regional languages of the Italian mainland are from 2002 data.

${ }^{6}$ According to Ethnologue (2017), only 3\% of Italy's population could speak standard Italian at the time of unification in 1861.

${ }^{7}$ Source: Ethnologue (2017)
} 
Seeing the trends for how European languages have typically been chosen for comparison studies, the question arises, how SHOULD one decide which of the Neo-Latin tongues to include in a cross-comparison linguistic analysis? It appears that the studies referenced above use the traditional criteria of number of speakers, or their status as a national language, or in the case of Hall for Sardinian, the fact that it is an isolated language. Both Hall and Rudder also include Romanian within their rosters of languages, most likely because of the geographical distance between Romania and the remainder of the Romance speaking world, as well as preexisting knowledge of the incorporation of Slavic elements into the Latin base, making it further interesting in terms of the identification of specific lexical and structural differences.

Another, very recent area of comparative inquiry in which Neapolitan appears to have been overlooked is in studies of lexical similarity. Such analyses, as stipulated by Ethnologue (2017), consist of comparisons of a set of standard word lists between two modern spoken language varieties and the assignment of a value to those forms that show similarity in both form and meaning. The values are then tallied to yield an overall similarity coefficient for the two languages compared. The higher the score, with 1.00 being the highest, the greater lexical similarity is alleged between the two varieties. Ethnologue (2017) reports the results of lexical similarity tests for a number of Indo-European languages that allow for lexical comparisons between say, English and French. It also allows for comparisons among the major Romance languages, with the exception, of course, of Neapolitan. Table 1 shows the results of such tests for some of the modern Romance languages. ${ }^{8}$

TABLE 1.

INDICES OF LEXICAL SIMILARITY BETWEEN SOME ROMANCE LANGUAGES (ACCORDING TO ETHNOLOGUE 2017)

\begin{tabular}{|c|c|c|c|c|c|c|c|c|}
\hline & Catalan & French & Italian & Portuguese & Romanian & Romansh & Sardinian & Spanish \\
\hline Catalan & 1.00 & $\mathrm{n} / \mathrm{d}$ & 0.87 & 0.85 & 0.73 & 0.76 & 0.75 & 0.85 \\
\hline French & $\mathrm{n} / \mathrm{d}$ & 1.00 & 0.89 & 0.75 & 0.75 & 0.78 & 0.80 & 0.75 \\
\hline Italian & 0.87 & 0.89 & 1.00 & $\mathrm{n} / \mathrm{d}$ & 0.77 & 0.78 & 0.85 & 0.82 \\
\hline Portuguese & 0.85 & 0.75 & $\mathrm{n} / \mathrm{d}$ & 1.00 & 0.72 & 0.74 & $\mathrm{n} / \mathrm{d}$ & 0.89 \\
\hline Romanian & 0.73 & 0.75 & 0.77 & 0.72 & 1.00 & 0.72 & 0.83 & 0.71 \\
\hline Romansh & 0.76 & 0.78 & 0.78 & 0.74 & 0.72 & 1.00 & 0.74 & 0.74 \\
\hline Sardinian & 0.75 & 0.80 & 0.85 & $\mathrm{n} / \mathrm{d}$ & 0.83 & 0.74 & 1.00 & 0.76 \\
\hline Spanish & 0.85 & 0.75 & 0.82 & 0.89 & 0.71 & 0.74 & 0.76 & 1.00 \\
\hline
\end{tabular}

According to Table 1, Spanish and Portuguese have an index of similarity at 0.89 , in other words, there is an $89 \%$ similarity between their lexicons. Similar tests for French and Italian yield the same score. Also interesting is the finding that Spanish and Italian only have an $82 \%$ similarity between them, suggesting that Italian is actually much closer to French than it is to Spanish, at least in terms of vocabulary. Once again, and in support of the claim I make for the apparent underrepresentation of Neapolitan among the ranks of European languages for comparison studies, what appear to be missing are similarity indexes for Neapolitan with these other languages. It is interesting that Ethnologue (2017) does indicate, however, that speakers of Italian from the north have indicated Neapolitan as being unintelligible.

Even with the absence of coefficients of lexical similarity specifically for Neapolitan, Ethnologue's recent assessments of lexical similarity for Spanish, Portuguese, Italian, and French should at least raise some questions regarding the methodology of language selection in such studies as Boyd-Bowman (1980) which was limited to the four major national Romance languages, as stated earlier. Considering that Spanish and Portuguese are deemed to be "close" on the one hand, and Italian and French are also "close," at least in terms of vocabulary, it would make sense that a wider spectrum of differentiation could possibly have provided greater objectivity in results. Nevertheless, the central point here is not so much to criticize previous studies, as it is to heighten the sense of urgency for the further examination of Neapolitan.

\section{The intrinsic value of national or mainstream language status as a criterion for linguistic analysis}

As Wright (2002) points out, the names that we use for languages are historically based on the names of places where they are spoken and have developed. They are nouns that have derived from what were originally adjectives representing a particular geographical sub-variety of some larger category of language, which in our present context would be Latin or Romance, e.g., Spanish Romance, French Romance, etc. ${ }^{9}$ Many of the names we use today for modern European languages correspond to those that have been adopted politically as national or official representatives to those countries where they are spoken. Such a designation of Italian as the overall representative language of Italy for comparative language studies has essentially left a wealth of data unexplored. Knowing a little more about the history of the Italian Peninsula and how this relates to the variety of different languages that have

\footnotetext{
${ }^{8}$ The notion of lexical similarity is not the same as that of intelligibility, being that the former is a simple bidirectional or reciprocal calculation. As explained by Ethnologue (2017), unlike the measurement of lexical similarity, that of intelligibility between two languages is a much more complex analysis that goes beyond the lexicon, involving other levels of linguistic structure such as phonology, morphology, and syntax.

${ }^{9}$ We see this in the use of such terms "American English, "Australian English," or "British English" which are used currently to distinguish between varieties. As Wright (2002) further explains, when varieties become no longer intelligible, the nominal component of the term disappears (as represented in the crossed-out portions of the forms mentioned here in the text) and the adjective itself becomes nominalized and henceforth stands alone to represent the particular variety.
} 
developed and are even still spoken there provides justification as to why Neapolitan should be considered more like a peer, rather than a minority, among the ranks of other European Romance languages that are typically evaluated in comparative studies.

Since the earliest times of Roman colonization there has existed an entirely different language in the south of Italy, which thenceforward throughout the ensuing centuries has developed in a unique way from how the language that we know today as Italian developed. In its evolution, the language that would eventually become Neapolitan was not limited to the city of Naples, but was spoken throughout the entire Kingdom of Naples, the largest of the Italian peninsula. Spanning the entire southern half of the Peninsula, below the area of the Papal States which included most of the Lazio region and Rome, the Kingdom of Naples' jurisdiction comprised what are today the modern regions of Abruzzo, Apulia, Basilicata, Calabria, Campania, southernmost Lazio, Marche, Molise, and Sicily. The Kingdom of Naples later became the Kingdom of the Two Sicilies, which remained designated as such until unification of the entire peninsula in 1861 into the singular Kingdom of Italy.

At the same time that we consider these historical facts, one must also keep in mind that the language that we know today as modern standard Italian originated in what was at one time no more than a dialect itself, limited to the geographical region of Tuscany. Tuscan, or toscano as it is known in the vernacular, was itself quite different from other dialects of the north, but for political and historical advantages, including economic and cultural prestige, has over time become the standard for the entire country following unification. Figure 1 demarcates the regions across Southern Italy where Neapolitan and its related varieties are still "vigorously" spoken.

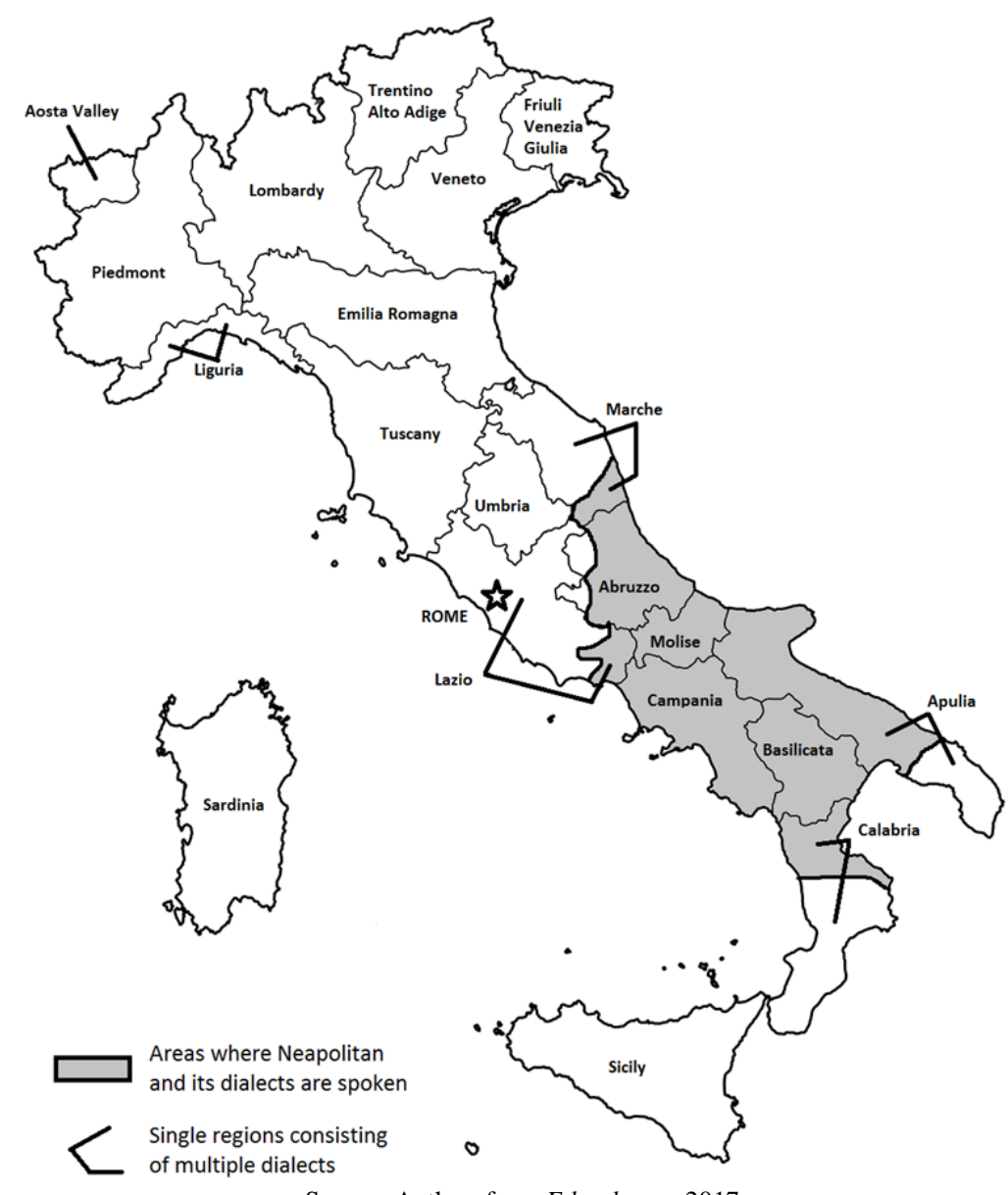

Source: Author, from Ethnologue, 2017

Figure 1. Regions in Italy where Neapolitan and its continuum of subdialects are spoken

It is interesting, though not at all surprising, that the shaded regions of Figure 1, demarcating the modern areas of Italy in which Neapolitan and its varieties are still spoken, are those corresponding to the very expanse of the region that embodied the one-time Kingdom of Naples. This in itself is an important finding in that one has to consider what would have happened historically, 1) had the south been stronger enough to assert itself as a separate power politically, and 2) had Italy not united with the south as a result of unification. In either case, Neapolitan could very well have become a so-called "major" European language on its own and in its own right, along the same lines as French, Italian, or Spanish.

The truth of the matter is that the south and north of Italy experienced two separate evolutions both politically and linguistically, and although the purpose of this paper is not to provide an exhaustive comparative historical account, some of the more noteworthy milestones are worth mentioning in order to understand the factors which determined the 
ultimate political and economic misfortunes of the southern Italian region, and in turn how the language which developed there could have retained some of its more unique characteristics.

\section{The history of Italy's south}

As historian Astarita (2006) suggests, the southern region of the Italian peninsula has always been one of sharp contrasts, a dichotomy between Naples and other western coastal cities as major urban centers on the one hand, while on the other, the remote, inner regions and eastern coastal cities remained less favorable and therefore, underdeveloped. Many emperors and other important and influential Romans built villas on the southwestern coastline in or very near Naples, such as the Isle of Capri. In ancient times Naples, together with its immediately surrounding area, was considered a unique, beautiful and strategically placed port city and for this reason was always coveted by successive powers, first the Greeks who gave the city its name "Neapolis," to be followed by the Romans, Byzantines, Arabs, Normans, and the Kingdom of Aragon of Spain. ${ }^{10}$

Naples not only attracted the Roman elite, but over time continuously drew large numbers of the common populus as well from the poorer agricultural areas of the south. As Astarita points out, for sheer lack of available space, the many who were attracted to Naples as an urban center were forced to build vertically, with towering apartments of six or seven floors that would typically not allow sunlight onto the streets below. This continued trend has made Naples today the third largest city in Italy, with a staggering population that would leave an indelible mark on any future development.

Another factor that has contributed to the paradox of Italy's south is its economy, which played a major role in its political unfolding as well. Throughout most of its early history, despite the attraction of Naples as an urban center, the fertile soil throughout the Mezzogiorno would provide the basis for a strong feudal economy in most outlying and remote areas. Political power was therefore always decentralized and exerted by local barons. Even under its 400 -year domination by the Spanish, the region was never governed centrally by the viceroy as its own nation, but rather more like a secondary power or colony, and usually from a distance. ${ }^{11}$ This allowed for the continuation of local policies, ways, and institutions for centuries. By the time of Italian unification in the late nineteenth century, new policies from Rome and further north seemed foreign to the ways of the south, but would eventually usurp them nonetheless.

Astarita capsulizes this dichotomy of the south best in the following excerpt from Between Salt Water and Holy Water:

"At the end of the first millennium...the diversity and prosperity of the Italian South were largely limited to its urban coastal areas. Calabria, Abruzzo, and most inner regions--largely mountainous, difficult to reach, and ungenerous to agricultural efforts--remained poor, rural, and culturally and religiously isolated. The few existing inland towns remained quite different from the dynamic centers on the coasts. They resembled large villages, with little of the commercial vitality, cultural diversity and varied activities and opportunities of the coastal cities, a difference that one can observe to this day

"This strong contrast between the urban and rural worlds is a prominent element of all Italian history since antiquity, and it was especially conspicuous in the early medieval south. Later, the growth of a strong central state and spread of the feudal system further reinforced this contrast and reversed the traditional power relations between the two worlds."

(Between Salt Water and Holy Water, Astarita p. 20)

To conclude, it was this special combination of factors that would essentially seal the fate of Italy's south as a secondary force, and its language to be considered minority among the other mainstream languages of Europe.

The intrinsic value of number of speakers as a criterion for linguistic analysis

Adding to the matter discussed in the previous section whereby Neapolitan is not considered a national European language, another factor that appears to have obscured the relative importance of Neapolitan and that may have also contributed to the inattention paid to it in comparison studies may have been its seemingly reduced importance as suggested by its total number of speakers. Table 2 shows the most recent data (at the time of this writing) as provided by Ethnologue's 20th edition (2017), which lists Romance languages according to their reported total numbers of L1 speakers worldwide.

\footnotetext{
${ }^{10}$ As Astarita (2006) points out, although the city of Ostia was considered to be the official port of the empire, the Romans utilized several other ports in the south as well, which included the port in Pozzuoli (near Naples) to receive the majority of its grain from Egypt. Ostia would eventually meet its ultimate demise when it would be buried underneath the silt accumulated from the Tiber, which flowed into it.

${ }^{11}$ Spain's four hundred-year presence in Naples had a profound effect upon the Neapolitan lexicon, having contributed an estimated 400 hispanicisms (Thomas, 2006).
} 
TABLE 2.

\begin{tabular}{|c|c|c|}
\hline Language & L1 speakers worldwide & (rank) \\
\hline Spanish/Castilian & $436,667,750$ & 1 \\
\hline Portuguese & $218,765,470$ & 2 \\
\hline French & $76,096,430$ & 3 \\
\hline Italian & $63,370,110$ & 4 \\
\hline Romanian & $24,150,840$ & 5 \\
\hline Neapolitan & $5,700,000$ & 6 \\
\hline Sicilian & $4,700,000$ & 7 \\
\hline Catalan & $4,105,420$ & 8 \\
\hline Galician & $2,340,000$ & 9 \\
\hline Sardinian & $1,100,000$ & 10 \\
\hline Friulian & 300,000 & 11 \\
\hline Asturo-Leonese & 110,000 & 12 \\
\hline Occitan & 218,310 & 13 \\
\hline Aragonese & 10,000 & 14 \\
\hline
\end{tabular}

Source: Ethnologue (2017)

Like national language status, the reported number of L1 speakers worldwide is another factor that is closely tied to the historical record, as Table 2 suggests. Empire building and emigration have been the primary contribution to the status of Spanish-Castilian, Portuguese, and French as being the three Romance languages with the largest number of L1 speakers, particularly in the cases of Spanish and Portuguese. It is interesting that Neapolitan-Calabrese ranks in 6th place overall, and in second place in terms of languages spoken in the Italian peninsula. However, remember that these are calculations of L1 speakers on a global scale. If we consider these same languages, but on a reduced scale, namely, as they are spoken within their base countries in Europe, according to Ethnologue (2017), as an attempt to understand the effects and power of these languages, minus emigration, we find the results in Table 3 .

TABLE 3.

\begin{tabular}{|c|c|c|}
\hline Language & L1 Speakers in base country & (rank) \\
\hline French & $60,000,000$ & 1 \\
\hline Italian & $57,700,000$ & 2 \\
\hline Spanish-Castilian & $38,400,000$ & 3 \\
\hline Romanian & $19,900,000$ & 4 \\
\hline Portuguese & $10,000,000$ & 5 \\
\hline Neapolitan & $5,700,000$ & 6 \\
\hline Sicilian & $4,700,000$ & 7 \\
\hline Catalan & $3,750,000$ & 8 \\
\hline Galician & $2,340,000$ & 9 \\
\hline Sardinian & $1,100,000$ & 10 \\
\hline Friulian & 300,000 & 11 \\
\hline Occitan & 110,000 & 12 \\
\hline Asturo-Leonese & 100,000 & 13 \\
\hline Aragonese & 10,000 & 14 \\
\hline
\end{tabular}

As compared to Table 2, Table 3 shows an interesting twist in terms of ranking by number of L1 speakers, with French being the most spoken, Italian, in second place, and Spanish placing third. Portuguese, which when considering global speakers places second, now falls into fifth place, just above Neapolitan, which continues in sixth place.

The topic of emigration, as we see in the comparative estimates between Tables 2 and 3, becomes even more important if we consider the other historical reality that obscures the case of Neapolitan in terms of overall number of speakers, and that is, the case of historic mass migration from Italy's south to other places, primarily the Americas, between the years 1880 and 1915, It has been reported that during this period, approximately 15 million Italians left Italy for other places, 4 million of whom would settle in the United States alone. Numbers further show that a full threefourths of newcomers that came to the United States were from Italy's southern regions.

The linguistic implications for this major historical event are huge when one considers the secondary effect of this particular large wave of emigration from Italy being that of language loss. The overwhelmingly large numbers reported in Table 1 for the number of L1 speakers of Spanish and Portuguese worldwide have very much to do with the fact that these languages crossed the seas at a time when they were intended to impose themselves as a means to expanding 
empires, and would henceforth become the primary languages spoken in the conquered territories and contribute to their respective exponential increases in number of speakers.

Much to the contrary, the huddled masses of southern "Italians" most poorly educated, many even illiterate and monolingual in Neapolitan or Sicilian, did not embody the expansionist spirit of the settlers of yore, but rather abandoned their homeland at a later historical period when the imposition of languages such as English in the United States or Canada, or Spanish or Portuguese in Latin America, had already taken place and were firmly established national languages. Italian emigrants of this period left Italy for better lives in places where their language would disappear within three generations. As I point out in Ryan (2017), this is particularly evident in the immigrant newspaper experience in North America whose articles were at first published exclusively in Italian at the beginning of the twentieth century, becoming bilingual Italian/English within twenty-five years after that and by the 1960s, were fully monolingual English.

\section{B. Demonstration from the Neapolitan Lexicon}

As a way of demonstrating the need to include Neapolitan in more comparative studies of the Romance languages, the final part of this paper is intended as an initial foray into lexical comparison. As pointed out earlier, Neapolitan has yet to be formally analyzed in terms of studies of lexical similarity as has been done for other Romance languages and reported in Ethnologue (2017). Although the analysis here is not intended to be exhaustive, it helps elucidate the potential benefits that a more comprehensive analysis would provide. As such, what I provide here is the examination of a limited number of everyday human items from the Classical Latin lexicon and compare these to cognate items in Neapolitan, Spanish and Italian in order to illustrate what appears to be the more archaic nature of Neapolitan vocabulary, and in some cases, despite its contiguous geographic location with Italian, a closer relationship to Spanish than is found for Italian. This section also explores the idea that by comparing current modern forms of sibling languages some additional insight can also emerge into forms that existed in some version of one or more of those languages in the past, and most particularly in this case, Spanish.

Consider the original Latin words in the first column of Table 4 for some of the more basic human concepts, as well as their ensuing reflexes in the three Romance languages compared.

TABLE 4.

\begin{tabular}{|c|c|c|c|c|c|}
\hline & & LATIN & Neapolitan & Spanish & Italian \\
\hline nouns & $\begin{array}{l}\text { (a) } \\
\text { (b) }\end{array}$ & $\begin{array}{l}\text { SORORE 'sister' } \\
\text { FRATRE 'brother' }\end{array}$ & $\begin{array}{l}\text { sora } \\
\text { frate }\end{array}$ & $\begin{array}{l}\text { hermana } \\
\text { hermano }\end{array}$ & $\begin{array}{l}\text { sorella } \\
\text { fratello }\end{array}$ \\
\hline verbs & $\begin{array}{l}\text { (c) } \\
\text { (d) } \\
\text { (e) } \\
\text { (f) }\end{array}$ & $\begin{array}{l}\text { DICERE 'say' } \\
\text { EXITARE 'to awaken' } \\
\text { IRE 'to go' } \\
\text { EAMUS 'let's go' }\end{array}$ & $\begin{array}{l}\text { dicere } \\
\text { ascetà } \\
\text { ghì } \\
\text { iamma }\end{array}$ & $\begin{array}{l}\text { decir } \\
\text { despertar } \\
\text { ir } \\
\text { vamos }\end{array}$ & $\begin{array}{l}\text { dire } \\
\text { sveglare } \\
\text { andare } \\
\text { andiamo }\end{array}$ \\
\hline other & $\begin{array}{l}\text { (g) } \\
\text { (h) }\end{array}$ & $\begin{array}{l}\text { CRAS 'tomorrow' } \\
\text { (DE) IN ANTE 'before' }\end{array}$ & $\begin{array}{l}\text { craje } \\
\text { 'nnante }\end{array}$ & $\begin{array}{l}\text { mañana } \\
\text { delante }\end{array}$ & $\begin{array}{l}\text { domani } \\
\text { davanti }\end{array}$ \\
\hline & & same lexemes & & new lexe & \\
\hline
\end{tabular}

Source: Author

If we compare the overall number of original Latin words in Table 4 that have continued into the three daughter languages compared, the first striking observation that one can make is that all eight words in Neapolitan have descended directly from their Latin equivalents (hence, the gray shading of all these words). Moving to the case of Spanish in the next most column we see that only three of the original Latin lexemes have continued into Spanish, and in the last column, Italian has also only retained one of these. ${ }^{12}$

Looking more closely at the examples in Table 4, we also notice that Neapolitan has retained Latin forms across all grammatical categories. In terms of examples (a) and (b), we see that the nouns SORORE 'sister' and FRATRE 'brother', have continued into Neapolitan with the same meanings of their Latin predecessors. Spanish has replaced these with the new words hermano and hermana which stem from the original paired forms FRATRE GERMANO 'full (as opposed to half) brother' and SORORE GERMANA 'full sister,' and truncated to employ only the second word of

\footnotetext{
${ }^{12}$ An important aspect of lexical similarity studies mentioned earlier in this chapter is that they compare cognates not just in form but also in meaning. The results in Table 3 similarly consider words that retain both form AND original meaning. If original forms have drifted in meaning in a particular daughter language and another word has replaced the original form, the evolved form is not considered a true cognate.
} 
the original pairs. As the table also indicates, Italian has diminutivized the original forms into fratello and sorella. ${ }^{13}$ Remarkably, of the three languages compared, Neapolitan is the only language that retains both the original form AND meaning of the CL lexemes.

If we turn to the verbs in examples (c) through (f) of Table 4, we likewise see retention in Neapolitan of original Latin forms with their corresponding meanings, while Spanish has only retained two of these original forms to mean the same thing, and Italian, only one, though it has truncated this one case with the innovation dire. In the case of example (d) EXITARE 'to rise, wake up' Neapolitan is the only of the three languages that has retained its original meaning in ascetà, although Spanish and Italian possess the later borrowed words excitar and eccitare, respectively, and in contrast, both mean 'to excite.' In a way that is very similar to the cases of both nouns FRATRE and SORORE, the verb EXITARE appears to have evolved semantically to have a more figurative meaning in both Spanish and Italian than it does in Neapolitan.

The case of (e) IRE 'to go' is an interesting one as we compare it across all three languages. The Latin verb IRE was a lexical item that in some cases underwent different manifestations of suppletion with the verbs VADERE 'to go forth', and AMBULARE 'to walk' in the daughter languages. As Table 4 suggests, the original infinitive was maintained both in Neapolitan as ghì and in Spanish as ir. However, in Italian the infinitive has been replaced by andare. Another particularly interesting fact about this verb in Neapolitan, is that in addition to retaining the original Latin infinitive, some of the conjugated verb forms were retained as well, such as (f) iamma 'let's go,' are direct reflexes of the CL verb form, all but lost in other Romance varieties, in this case the first person plural present subjunctive form EAMUS from IRE 'go.'

In the table's "other" category, we have the adverb CRAS 'tomorrow' in (g) which has been maintained in Neapolitan as craje, but lost in both Spanish and Italian to mañana and domani, respectively.

More interesting still is the fact that the previously existing form cras has been documented in older forms of Spanish as found in (1)

(1) "...hoy es dia bueno y mejor sera cras"

'...today is (a) good day and better it will be tomorrow'

Cantar del Mío Cid (c. 1140)

Another category where we see some evidence that Neapolitan has a potentially closer relationship with Spanish than Italian is in that of newer prepositions that have been constructed from the combination of earlier prepositional sequences. These have since been replaced in Italian by other formations. Consider the case of (h) (DE) IN ANTE, which has continued both into Neapolitan as 'nnante 'before,' and into Spanish as delante, created by regressive dissimilation of the first $-\mathrm{N}$ - into a liquid. ${ }^{14}$

Similar to the older evidence for CRAS above, an attested previously existing form of Spanish in denante has likewise been documented in earlier documents, such as (2).

(2) "...cum sua ecclesia et suo molino, qui est ibi denante"

'...with his church and his mill, which is there in front'

Pedro I al obispo de Huesca., Documentos notariales (c. 1098) (Seco, 2003)

It is interesting that this DE IN ANTE pattern that is found in both Spanish and Neapolitan, is not found in Italian (or French) which instead relied on the entirely different combination of DE AB ANTE ultimately yielding davanti. The parallel of this combination, DE EX POST, also occurs in Spanish después 'after.'

In summary, though not intended to be comprehensive, the examples of common words in Table 4 suggest three areas where Neapolitan stands out as compared to its Romance peers in terms of the lexicon, namely, 1) modern Neapolitan appears to preserve several of the original forms and meanings of original Latin words for basic everyday concepts; 2) although Spanish and Italian have replaced some original Latin lexemes with innovations, in some cases the original Latin forms still exist but their meanings have drifted over time; and 3) although some words have been replaced entirely and no longer exist in modern Spanish and Italian they have been documented as having existed at one time.

Moreover, the analysis presented here gives further credence to the importance of including Neapolitan with those other previously mentioned Romance languages that have been the subject of former lexical similarity studies. Such a study would perhaps provide additional details beyond those presented here, such as the case of Spanish delante and Neapolitan 'nnante, where lexical convergence helps document common paths of evolution. The archaic nature of the Neapolitan lexicon, whether these be classical or later Latin forms, also implies the merits of future analysis of other linguistic structures at the phonological, morphological, and syntactic level.

\section{CONCLUSION}

I would argue that, because of the observations made in this preliminary comparative lexical study, and despite its distance from the Iberian Peninsula, Neapolitan might serve as an interesting test case for the notion of an early Pan

\footnotetext{
${ }^{13}$ It is important to clarify here that although both Spanish and Italian have also retained reflexes of the original forms SORORE and FRATRE in the words sor/suora and fraile/frate, respectively, these are reserved strictly for use by the religious professions, much like we use the English terms "sister" for nuns and "brother" for some male clerics.

${ }^{14}$ This regressive dissimilation occurred in Spanish in other words such as VENENU(M) 'poison' which rendered veleno.
} 
Romance, a theory proposed by Wright (2002) that the language spoken across the expanse of the Roman empire throughout the first and into the second millennia CE was a complex ensemble ${ }^{15}$ consisting of several different social registers, one of which was standard written Latin, intelligible even to the uneducated when read aloud logographically until the 10th through 13th centuries CE, as well as a less formal one, both of which originally included a wide repertoire of possible ways of expressing the same idea, but would ultimately settle on a particular one or few in that particular region.

The notion of an early Pan Romance challenges the alternate, traditional stance that: 1) isolation and regional differences among the imperial colonies would have had an immediate effect on both manner and timing of how Latin in different regions would further partition, and 2) further differentiation between regions would have happened more or less immediately, and continued to produce the geographically-based Romance language varieties we have today.

Instead, according to Wright, the Pan Romance approach proposes that early Romance was actually quite uniform in the sense that all Roman colonies drew upon the same repertoire of possibilities of expression, and would only eventually adopt the variation specific to that locality. To illustrate this very notion, one such example of the wide variety of options available to speakers is that of Romance plurals, which would ultimately differ in two possible ways across the empire, either of which depending upon the particular tolerance for final consonants. Depending on the declension to which a particular noun or adjective belonged, as well as the case form it embodied for a particular function in the sentence, the pluralization of nouns in Classical Latin could occur in three possible ways, namely, via the final vowels -A or -I, the diphthong -AE, or word-final -S. It has been suggested that over time the overall degradation of the CL case system contributed to the adoption across the empire of what appears to have been the accusative form as the single case form that would be used thereafter for all functions within the sentence, with some limited variation. Relevant to the discussion here is the fact that the ending of the plural accusative was almost always with final -S, except in the case of neuters, which was final -A. Because the type of Romance that was developing in the Italian Peninsula exhibited a strong intolerance for word final consonants, including -S, Italian and other Italic varieties would retain the final $-\mathrm{S}$ for the plural accusative, but, as has been proposed by Rohlfs (1966) and others, would eventually vocalize this $-\mathrm{S}$, which would then cause further phonological change to the forms we have today, all of which are final vowels. In contrast, Ibero and Gallo Romance exhibited greater tolerance for final consonants and therefore retained the final -S for plurals, and would even extend this form for words that formerly ended in -A as well. In either case, the point is that both forms were available in Classical Latin, but only one of the two would be adopted system-wide by and for particular languages.

\section{ACKNOWLEDGMENTS}

The author wishes to thank the University of Northern Colorado for its generous support of a Provost Travel Award to present this work at the $11^{\text {th }}$ Annual Conference of Languages and Linguistics in Athens, Greece. Publication of this article was also funded in part by the University of Northern Colorado Fund for Faculty Publication.

\section{REFERENCES}

[1] Abete, G. (2011). I processi di dittongazione nei dialetti dell'Italia meridionale. Un approccio sperimentale. Roma: Aracne.

[2] Agard, F. (1984). A Course in Romance Linguistics. Washington, D.C.: Georgetown University Press.

[3] Astarita, T. (2006). Between Salt Water and Holy Water: A History of Southern Italy. W. W. Norton \& Company.

[4] Banniard, M. (2013). The transition from Latin to the Romance Languages. In The Cambridge history of the Romance languages. Vol. II. Contexts. Cambridge, Cambridge University Press.

[5] Bartalesi-Graf, D. (2011). Voci dal Sud: A Journey to Southern Italy with Carlo Levi and His Christ Stopped at Eboli. New Haven: Yale University Press.

[6] Boyd-Bowman, P. (1980). From Latin to Romance in Sound Charts. Washington, D.C.: Georgetown University Press.

[7] Cantar de Mío Çid. (c. 1140). Downloaded on 6/21/2015 from http://www.vicentellop.com/TEXTOS/miocid/miocid.htm.

[8] Clivio, G., Danesi, M. and Maida-Nicol, S. (2011). An Introduction to Italian Dialectology. Munich: LINCOM, 2011.

[9] Hall, R. A. (1976). Proto-Romance Phonology: Vol. II (Historical Comparative Romance Grammar). New York/Cambridge/Amsterdam: Elsevier Science Ltd.

[10] Hall, R. A. (1984). Proto-Romance Morphology: Comparative Romance Grammar, Vol. III (Current Issues in Linguistic Theory). Amsterdam/Philadelphia: John Benjamins.

[11] Ledgeway, A. (2009). Grammatica diacronica del napoletano. Tübingen: Max Niemeyer Verlag.

[12] Loporcaro, M. (2016). Metaphony and diphthongization in Southern Italy: Reconstructive implications for sound change in early Romance." In Approaches to Metaphony in the Languages of Italy, F. Torres-Tamarit, Linke, K., and van Oostendorp, M. Eds. Berlin: De Gruyter

[13] Maiden, M. (1995). A Linguistic History of Italian. London: Longman Linguistics Library Series, Routledge.

[14] Rohlfs, G. (1966). Grammatica storica della lingua italiana e dei suoi dialetti. Fonetica. Torino: Piccola Biblioteca Einaudi.

[15] Rudder, J. (2012). The Grammar of Romance: A Comparative Introduction to Vulgar Latin \& the Romance Languages. Charleston: CreateSpace Independent Publishing Platform.

\footnotetext{
${ }^{15}$ Term coined by Banniard (1992) and utilized by Wright (2002).
} 
[16] Ryan, J. M. (2017). Glimpses of Proto-Ibero-Romance through Neapolitan and other southern Italian mainland vernaculars. In Contemporary Advances in Theoretical and Applied Spanish Linguistic Variation, J. Colomina-Almiñana, Ed. Columbus: Ohio State University Press.

[17] Ryan, J. M. (2017). Astride two worlds: Emergence of Italian-American identity in the Massachusetts immigrant press.” In Palander-Collin, R. and Taavitsainen, X., Eds. Diachronic Developments in English News Discourse. Amsterdam/Philadelphia: John Benjamins.

[18] Seco, M. (Ed.). (2003). Léxico hispánico primitivo. Madrid: Espasa Calpe.

[19] Simons, G. F. and Fennig, C. D., Eds. (2017). Ethnologue. Languages of Africa and Europe. Dallas: SIL International Publications.

[20] Thomas, J. (2006). Hispanismos en Napolitano. Doctoral dissertation. University at Albany, State University of New York.

[21] Vincent, N. (1990). Italian. In The World's Major Languages, Comrie, B, Ed. New York: Oxford University Press.

[22] Wright, R. (2002). A Sociophilological Study of Late Latin. Utrecht Studies in Medieval Literacy. Belgium: Brepols Publishers.

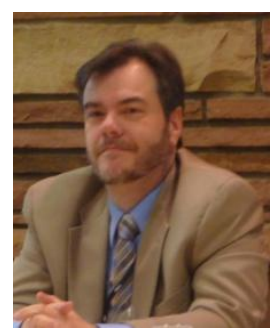

John M. Ryan earned his Ph.D. in Rhetoric, Composition, and Linguistics at Arizona State University in Tempe, Arizona, USA in 2008. He earned his Master's degree in Spanish linguistics, also from Arizona State, in 1991. He earned his Bachelor of Science degree in Spanish from Georgetown University's School of Languages and Linguistics in Washington, D.C. in 1985.

He is currently Associate Professor of Spanish Linguistics at the University of Northern Colorado. His research on the acquisition of verbs by children and adults has been published in such journals as the Journal of Child Language and Development, the Journal of Language Teaching and Research, and Hispania. His first book, The genesis of argument structure: Observations from a child's early speech production in Spanish (Germany: Lambert, 2012), traces the emergence of the verb phase in the developing language of a monolingual child learning Peninsular Spanish. Other interests include historical news discourse of the Italian American community and the reconstruction of proto Ibero Romance, for which he has recently authored several scholarly papers for different edited volumes.

Dr. Ryan is a member of the Linguist List International Linguistics Community, the Societas Linguistica Europaea, the Linguistic Society of America, the Rocky Mountain Modern Language Association, the Linguistic Association of the Southwest, the National Italian American Foundation, and the Italian American Historical Society. 